\title{
農山村過疎地域における転出・帰還行動の モデル化に関する基礎的研究 \\ A DYNAMIC OUT/IN-MIGRATION MODEL FOR RURAL DEPOPULATION PROBLEMS
}

\author{
片田敏 孝*・廣畠 康 裕**・青島縮次郎*** \\ By Toshitaka KATADA, Yasuhiro HIROBATA and Naojiro AOSHIMA
}

\begin{abstract}
Rural depopulation problems in Japan are caused by excess of out-migration from rural areas. The out/in-migration of a person from a rural area is based on the evaluation of his/ her life environment. Its process is dynamic and different from each other according to his/ her life cycle stage and individual attributes. The effects of countermeasures for rural depopulation problems should be estimated by amount of out/in-migration through such decision making process. Standing on these viewpoints, we have developed a Dynamic Out/ In-Migration Model by using Dimension-Nested and Time-Nested Logit Model.

Keywords : rural depopulation problems, out/in-migration, dynamic choice model
\end{abstract}

\section{1.はじめに}

地方定住の促進施策は，人口減少の進む地方圈ではも とより，国土の有効利用や保全といった面で国土計画的 にも重要な施策として位置付けられている. 地方定住構 想を唱った三全総, 多極分散型国土形成を唱った四全総 など，国土開発の基本構想はまさにこれを反映した経緯 をたどっており，新旧過疎法などの法体系に基づく地方 定住の促進施策も，その一環として今日まで漸次進めら れてきた，その結果，近年になり地方都市やその近郊の 農山村では, 居住環境の向上が図られており, 人口の流 出傾向の鈍化, 帰還者の増加等, 定住化の進展が認めら れる地域も少なからずみられるようになっている。しか し, 定住化の進展がみられる地域においても, 地域社会 を健全に維持し得るほどの人口規模がいまだ確保されて いない地域が多いこと，地方都市から遠隔の農山村では 今日なお過疎化が進展していることなどの現状をふまえ るならば，より一層の施策が望まれる。

過疎現象は，地理的位置など，地域固有の条件が密接

* 正会員 工博 (侏東海総合研究所調查研究部研究員 ( 4460 名古屋市中区錦 3-20-27)

** 正会員 工博 豊橋技術科学大学助教授 工学部建設工 学系 (T441 豊橋市天伯町雲雀ケ丘 $1-1$ )

*** 正会員 工博 群馬大学教授 工学部建設工学科 (テ376 桐生市天神町 $1-5-1$ )
にかかわる，したがって，定住施策の実施においては， 施策の対象地域における過疎化がいかなる背景や機構で 生じた現象であるのかを十分に分析したうえで，施策の 効果が事前に評価検討されることが望まれる.しかし， そのための方法はいまだ確立されていないのが現状であ る.

地方定住や過疎問題に関連する研究は, 従来より数多 くなされている.これらは, (1)過疎の実態分析を行い, その中から定住施策のあるべき方向性を検討した研

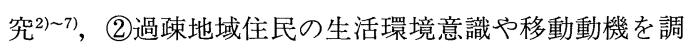
査し, それに基づき定住施策の方向性を示した研究8) 10), (3)過疎地域の地域運営を経済学的観点から考察した研 究 ${ }^{11), 12)}$, (4)具体的な定住施策を挙げ, その効果についての

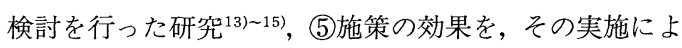
る移動量の変化から定義し，施策そのものの評価を試み た研究16),17)，などに分けることができる。ここで，施策の 効果をその実施に伴う転出・帰還量の変化と定義し, そ の予測を行うための分析を定量的分析とするなら，(5)が これにあたる.このうち, 定井らの研究 ${ }^{16)}$ は, カ夕ストロ フィー理論を用いてモデル構築を行った先駆的研究であ $\eta$ ，過疎対策と挙家離村の関連を定量的に分析したこと などにおいて参考となるところが多い.しかし，この研 究で扱っている移動形態は, 挙家離村という限られた移 動形態であり，多様な移動形態の中で生じる過疎問題の 一般的な対策効果を論じるには必ずしも十分ではない. 
また, 片田・青島・氷鉋 ${ }^{17)}$ は, 世帯のライフサイクルを考 慮した居住地·従業地の同時決定モデルを提案している. この研究では, 農山村における転出・帰還行動は, 世帯 のライフサイクルや従業地選択行動と密接なかかわりを もつことを指摘し, それを考慮したモデルの定式化を 行っているが, 農山村と都市から成る 2 地点間モデルで あることなど, 適用性において問題を残している.

このように, 定住施策の効果を事前評価するための分 析手法が今日まで十分に研究されなかった背景には, ま ず先に述べたように，問題が地域固有の条件のもとで生 じているため, 移転性のある汎用的な分析手法の開発が 困難と思われていたことが考えられる。しかし, 定住化 の進展がみられる都市近郊の農山村から，過疎化が著し い山間内部の農山村までを対象とした, 著者らの一連の 研究6),7),15)によれば，農山村住民の転出・州還行動には, 過疎化の程度や地域の特性に依存しない共通した行動規 定要因が存在することが認められており，これらの要因 や地域固有の条件を積極的に扱うことで，移転性のある 分析手法の開発は成し得るものと考えられる.また，こ れ以外の背景としては，手法開発のためのデー夕収集に は労を要すること, 手法開発の必要性が十分に認識され ていなかったこと, などが考えられる。しかし，広範な 過疎地域において, 定住施策を実施するには多大な費用 が必要であり，この意味においての制約も多い.このた め, 施策の実施には, 事前評価に基づく効率性が求めら れ，そのための手法開発は意義あることと思われる.

本研究では, このような背景を受けて, 定住施策の実 施による転出行動の抑制効果や帰還行動の促進効果を, 転出・帰還行動モデルを構築することで子測を可能とし, その適用による施策の事前評価に基づく，より効果的な 定住施策の実施に資することを最終的な目的としてい る.このうち本稿では, まず, 定住施策の評価の考え方 を整理し, 次に, 転出・帰還行動のメカニズムを考察し, これを踏まえて，予測をいかに行うべきかを検討する. さらに, 定住施策評価を可能とする転出・帰還行動モデ ルの構造や組み込むべき説明変数についての考察を行 う. 最後に, 以上の検討をふまえたモデルを作成し, 調 查データによりその妥当性を検討するとともに，今後， より実用的な定住施策評価を行うためのモデル開発の方 向性を示す.

\section{2. 転出・帰還行動分析の枠組み}

過䛢な人口減少が地域社会の健全なる維持を困難にす るいわゆる過疎の状態では, 一般に以下のような過疎問 題が生じる. (1)社会的分業の機能が失われ，防災，教育， 保健，消費など，地域社会維持の基礎的条件に支障をき たす. (2)労働力と就業機会の質的，量的な悪化が相互に
影響を与えあいつつ進行し, 就業環境の悪化とそれに伴 う生活基盤の摇らぎが生じる. (3)農林業の担い手が不足 することにより, 田畑山林等の荒廃が進む. (4)公共サ一 ビスの採算性が悪化するため, 多大な補助金を投じて サービス水準を維持するか, サービス水準を低下せざる を得ない状況が出現する.

過疎が進行する過程においては, これらの過疎問題が, 一方で地域住民の転出に拍車をかけ，他方ですでに転出 した住民の帰還を思いとどまらせるといった悪循環が生 じる.したがって，過疎問題の根本的な解決を目指すな らば，過疎対策を，単に過疎地域に生じた問題への個別 の対応としてのみ実施するのではなく，過疎化過程にお ける悪循環からの脱却に対して，より効果的に実施する ことが重要であると考えられる，なお，本研究では，過 疎対策のうちこの悪循環からの脱却に対して特に効果的 な施策を定住施策とよんでいる.

このような観点から今日の過疎対策を概観すると，そ の多くは，個々の問題の解決により重点が置かれている ように思われる.たしかに，それら問題の解決を図り， 過疎地域の生活環境を向上させることは，過疎化過程に おける悪循環からの脱却に対して何らかの効果はある.

しかし，これら今日の過疎対策が，この悪循環からの脱 却に対して特に効果的に作用し, 長期的にみたとき, 地 域の活性化に有効な対策となる保証, すなわち, 本研究 でいう定住施策である保証はない.

定住施策は, 過疎化過程の悪循環のなかで進む, “転出 の促進と帰還の抑制”という流れを, “転出の抑制と帰還 の促進”へと効果的に転換を促す施策である. したがっ て，定住施策の実施にあたっては，住民の転出・帰還行 動に際しての意思決定のメカニズムをふまえ，施策の結 果として創出される生活環境が住民にいかに評価され， 転出・帰還行動に反映されるのかをふまえることがより 重要となる.

ところで，一般に農山村における過疎の程度や定住化 の進展状況を論じるとき, その説明指標には圈域人口や その増減が用いられてきた。しかし，過疎化過程の中で 機能する定住施策の効果を分析しようとする本研究の立 場からすれば，ある時点の圏域人口やその増減のみを もって定住施策の効果を論じることは，必ずしも妥当と はいえない，その理由として，圈域人口では，定住施策 の 1 次的効果としての社会増減とその結果を反映して 2 次的に生じる自然増減の区別ができず，さらに社会増減 を構成する転出, 㷌還の区別もできないため, 人口増減 のうち，施策の効果がどの程度あるのかを把握できない こと, などが挙げられる。 また, 現状の過疎問題を概観 すると，地域人口の総量が絶対的に少ないことに起因す るばかりでなく，地域の担い手として中心的な立場にあ 
る若青年層の不足も大きな要因となっており，この現実 をふまえるならば，個人属性（年齢等）別に転出・帰還 量が計られることがより望ましいと考えられる.

また，過疎化過程の脱却に対して，定住施策の効果を 考えるとき考慮されるべきことは，いかなる施策をいつ 実施したとき，いつの時点でどれだけの効果が生じるの かといったことである，そこで本研究では，施策の種類 と実施時期を政策変数とし，その効果の時系列的な発生 量の予測を行うことが重要であると考える.

以上の考察に基づき本研究では, 定住施策評価におけ る評価指標として, 時系列的に計測された, 属性別の転 出・帰還量が適切であるとの認識にたち，それを算定す るためのモデル構築に関する基礎的な検討を行うもので ある。

\section{3．農山村における住民移動の特質と炎のモ デル化の考え方}

\section{（1）転出・帰還行動の特質とぞの行動規定要因}

人口移動の計画学的研究には，2つの視点がある。そ の 1 つは, 都市圈内などの比較的狭い領域で行われる人 口移動としての視点であり，そこに存在する計画学的課 題とは住宅立地を中心とした土地利用に関する課題であ る。他の 1 つは，農山村都市間などの地域間にみられる 広域的な人口移動としての視点である。これに関する計 画学的課題とは, 都市の過密問題, 農山村の過疎問題と いった地域人口の総量や密度に関する問題である.

これら人口移動のモデル開発に関する研究は従来より 数多くがなされている。しかし，その多くは前者の視点 に立ったものである。これらの研究では, 立地効用や地 価などの立地条件が重要な説明要因とされ，それに基づ く個人の居住地選択行動（住宅立地行動）として人口移 動が报われている。しかし，後者の視点に立ち農山村の 広域的な人口移動を扱う本研究においては，都市域にお いて有効とされるこれら説明要因のみでは必ずしも十分 なものとはいえず，むしろ，農山村に特有の行動規定要 因や個人属性を重視することがより必要であると思われ る.

農山村から都市域への転出行動を促す要因としては, 農山村の相対的な生活（居住，就業）環境水準の低さを 挙げることができる。とりわけ農林業の不振により現金 収入の大半を $2 \cdot 3$ 次産業に頼る今日の農山村の就労構 造において, 就業環境水準の低さは転出行動の重要な要 因となっている。また，居住環境水準の低さ，すなわち 居住関連諸施設の整備水準の低さは，特に若青年層に対 して都市への憧憬の念を抱かせることになり，就業環境 水準の低さと相まって大きな転出促進要因となってい る。これらの転出促進要因は，同時に帰還抑制要因でも
あり，より良い生活環境を求めることにかかわる人口移 動要因であることにおいて都市域内での人口移動要因と 類似している。しかし，農山村においては，その地域で の居住が可能か否かにかかわる要因であることにおいて 都市域のそれとは本質的に異なっており，農山村に特有 の空間的条件となっている，また，道路整備，モータリ ゼーションの進展に伴い日常的な生活行動圈の広域化が 進む今日の農山村にあっては, 農山村そのものの生活環 境水準が低くても，生活行動圏内でその充足が可能とな る、そのため, 行動規定要因には近隣の都市域の生活環 境水準とそこまでのアクセシビリティも組み入れて考え ることが必要である。

農山村の人口移動を規定する要因としては，空間的条 件のほかに主体の条件として，家産の継承問題などがあ る、農山村にあっては, 先祖伝来の不動産（家産）の保 有率が著しく高く，それを継承する行為そのものが伝統 的不文律として今日なお重要視されている。これは農山 村住民の転出・帰還行動において, 最も特徵的かつ重要 な行動規定要因として位置付けることができる。また, 一般に家産の継承が行われていることは，意思決定者の 親が農山村に居住している場合が多いことを示す。した がって，意思決定者にとっての家産の継承行為は親の扶 養をも含んだ行為となるため，居住地を選択するという 行動を，農山村サイドにより強く規定する要因となるも のと考えられる。

なお，個人属性別の転出量，帰還量をもって定住施策 の評価を行うことの必要性については前述したが，転 出・帰還行動の行動規定要因である生活環境水準の認知

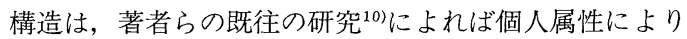
明らかな相違がある。また，転出・帰還行動を規定する 家産の継承についても, 長男か否かといった個人属性に 応じて規定の程度が異なっている。したがって，転出・ 㷌還行動を個人属性別に扱う必要性は行動規定要因の面 からも認められる。

\section{（2）転出・帰還行動における意思決定構造}

農山村における転出・帰還行動は, 行動の前後いずれ かの居住地が農山村に固定された広域的な居住地選択行 動とみなすことができる，このため本研究では，転出・ 帰還行動を広域的な居住地選択行動として扱っている. 一般に居住地の変更が広域的な領域で行われる場合, 居 住地の変更に伴い, 従業地や世帯構成など生活スタイル そのものも付随的に変更せざるを得ない事態が生じやす い.このため, 広域的な領域で行われる居住地の選択に おいては, 同時に従業地, 世帯構成も考慮されていると 考えられる．特に本研究のように農山村を対象とする場 合，世带構成の選択として親との同居を選ぶことは，多 くの場合，先に述べた家産の継承との関係において居住 
地を農山村に選ぶことに等しく，また，農山村を中心と した日常生活行動圈内に職（従業地）が得られない場合 にあっては，居住地を農山村に選択することが困難とな る。したがって，農山村住民の居住地選択における意思 決定の構造は，従業地，世带構成との同時選択構造を仮 定することがより現実的であると考えられる.

居住地，従業地，世帯構成の同時選択行動は，個人に とって長期の生活スタイルを想定する選択であることに おいて, 将来展望に立った選択行動であると考えられる。 この将来展望においては，個人は，今後将来にわたって 自らに生じる属性変化，ライフサイクルステージ（家族 の状態など）の変化や社会経済状況の変化を想定すると ともに，将来にわたり刻々と変化する属性やライフサイ クルステージのもとで，その時々の社会経済状況に対す る評価や嗜好の構造がいかに変化するかを認識している と考えられる。また，このような将来展望は，現状にお ける自らの属性などや居住地などの選択状態に依存して 行われる展望であり，一定時間の経過の後，実現した状 況が過去に行った展望と異なれば，その状況に基づく将 来展望を逐次あらためるものと考之られる．居住地，従 業地，世帯構成の同時選択行動は，このような将来展望 と現状に扔ける社会経済状況の総合的な考慮に基づく行 動であり，時間経過の中で生じる選択環境の変化の影響 を受けながら，その時点での行動主体にとって最善の生 活スタイルを逐次選択する行動であると考えられる。

\section{（3）モデルの考え方}

ここで構築されるモデルは，農山村に扔ける定住施策 の比較評価や実施順序決定を住民の転出，帰還行動から 捉えることを目的としている。したがって，このモデル では，現在もしくは任意の将来において何らかの施策が 施されたとき，行動主体が行うと考えられる居住地，従 業地，世带構成の同時選択行動が記述される。また，こ のモデル化においては，将来に実施される施策を行動主 体が完全に知り得るものと仮定し, 行動主体はその完全 情報下で，家産の継承なぞ種々の行動規定要因を総合的 に考慮し，常に最善の選択肢を選択するという合理的な 選択行動をとるものと仮定する。この場合の最善の選択 肢とは，必ずしも行動主体の満足度を最大にする選択肢 を指すのではなく，諸要因を勘案したうえで，行動主体 が選択するに最もふさわしい選択肢を指している。そし て，行動主体が常に合理的な選択行動を行うその基準と なる尺度をここでは効用と定義する。したがって，本モ デルは効用最大化行動として記述される。

本研究の効用の定義に従うならば，効用関数には行動 の際に考慮されることすべてが反映されていなければな らない.したがって，たとえば居住地選択の効用関数に は，選択時点の属性に基づき評価される居住環境を表現
するための社会経済情報に加えて，(1)同時選択を反映す るために世帯構成や従業地の情報が説明変数として盛り 込まれていること，(2)逐次効用最大化行動に関連して選 択時点の前期に扔ける選択状態が当期の条件付けとして 考慮されていること，(3)以上の考え方に基づく効用が将 来にわたって考慮されていることなどが必要である。

以上のように，本モデルでは，多様な個人属性や説明 変数で表わされる，居住地，従業地，世帯構成の同時選 択問題が逐次効用最大化の枠組みの中で扱われる。この ような場合，モデルの全体構成としては非集計ネス ティッドロジットモデルが適している。すなわち，この モデル形式を採用することで，各選択レベルの効用関数 に多様な個人属性や説明変数を比較的容易に組み込むこ とが可能になるとともに，多次元選択の同時選択問題を 効用最大化の枠組みの中で扱うことも可能となる.また, 逐次選択といった動的な選択構造についても，時間を離 散的に扱い，その時間に対してネスティッドな構造を与 えることで比較的容易な扱いができる。

なお，本モデルにおいては，直接的な行動分析対象者 を，分析対象農山村に本籍を有する世帯の主たる家計支 持者としている。その他の世帯構成員については，分析 対象者の従属者として扱うこととしている。この主な理 由は，本モデルが個人を対象にしていることから，すべ ての個人を対象とした場合，一世帯内での複数個人の行 動結果を必ずしも現実的な世帯としてまとまりのあるよ うに表現できるとは限らないことによる，また，非本籍 者については本モデル外で別途取り扱うものとする.

\section{4. 農山村を対象とした転出・帰還行動モデ ルの定式化}

ここでは，これまでに述べたモデル構築の基本的な考 之方に従い，世帯構成・居住地・従業地の同時選択モデ ルをランダム効用理論に基づく非集計行動モデルを用い て定式化する。

\section{（1）将来効用の考慮の方法}

本モデルでは，将来の各時点で行動主体が認識すると 思われる効用が，現時点の効用とともに現時点で評価さ れる。この際，現時点の効用と対等に扱うことには疑問 があり，不確定な将来の効用であるがための，何らかの 配慮が必要と考えられる。このため, 本研究では将来効 用に対して割引乗数 $C$ を導入し, 式 (1)のように扱うこ ととする。

$$
\widehat{U}(t)=U(t)+C \cdot U(t+1)+C^{2} \cdot U(t+2)+\cdots \cdots
$$

ここに, $\hat{U}(\cdot), U(\cdot)$ はそれぞれ将来を含めた効用と各時 点の効用を表わし，（）内は評価時点を表わす。なお， 割引乗数 $C$ の值は, 一期間をどれだけにとるかにより変 
わる.また，パラメーターの推定作業においては，割引 乗数 $C$ は通常のパラメーターに含まれた形で推定され るが，これによって効用最大化仮説の整合条件 ${ }^{18)}$ に影響 が及ぶことはない.

この定式化において将来効用を考慮する期間は，個人 が考える最遠の将来 $t+n$ 時点までであり, 現実的には, 行動主体が実際に考慮する将来の限界と考えても，存命 期間と考えてもよい.

（2）モデルの全体構成の概要と意思決定のツリー構 造

本研究では, 世帯構成, 居住地, 従業地といった多次 元選択の同時選択問題が動学的に扱われる.したがって, $t$ 時点での同時選択を表現するモデルは, 一期前(すなわ ち $t-1$ 時点) の選択結果を反映すること, 将来効用を考 慮すること，といった条件のもとで構築されることにな る.これに対応して本モデルは前期の選択状態に条件付 けられ，かつ，時間に対してネスティッドな（TimeNested）モデル構造を有する。このような時間に対する ネスティッドなモデル構造は, すでに Leonardi ${ }^{19)}$ などに より，タイムネスティッド・ランダム効用理論（Timenested randam-utility theory）として提案されている. 本研究では，これを離散的な時間の流れの中で扱うこと によりモデルに導入することとしている，また，世帯構 成，居住地，従業地といった多次元の同時選択問題にも ネスティッドロジットモデルを適用し，各次元レベルで 段階的にロジットモデルを適用するモデル構造をとって いるが, Time-Nested なモデル構造はこの中に組み込 まれた形で機能することになる，いま，同時選択という 意思決定構造を段階モデルで表現するためのツリ一が, 世帯構成, 居住地, 従業地の順であると仮定されるとき， その構造は, 図一 1 のようになる. 以下のモデルの定式 化は，図一 1 に示すツリーに従い世帯構成選択を例にと り行うこととする. なお, 居住地選択, 従業地選択の定 式化については，世帯構成選択のそれとほぼ同じ過程を たどるため，ここでは定式化された結果のみ記すことと する。

\section{（3） モデルの定式化 ${ }^{20)}$}

$t$ 時点における世帯構成の選択は, $t-1$ 時点の世帯構 成, 居住地, 従業地と, $t$ 時点での個人属性やライフサイ クルステージにかかわる属性に条件付けられ，そのもと で，将来効用を含め最大効用が得られると期待される世 帯構成が選択されると考える.すなわち, $t$ 時点での世帯 構成は, それ自身の効用と, その世帯構成のもとで行わ れる, $t$ 時点での居住地選択, 従業地選択, さらに $t+1$ 時 点以降の各時点の世帯構成選択, 居住地選択, 従業地選 択の組合せの最大効用との和が最大となるように選択さ れると考える.これに基づき， $t$ 時点での世帯構成 $h_{t}$ の
選択確率 $P_{h_{t} \mid S_{t}, h_{t-1}, i_{t-1}, j_{t-1}}$ (以下, $P_{h_{t} \mid}$.と略す）を定式的に 表わすと，次式のようになる。

$$
\begin{aligned}
P_{h_{t} \mid}= & \operatorname{Prob}\left\{\widehat{U}_{h_{t \mid} \mid t_{t}, h_{t-1}, i_{t-1}, j_{t-1}}>\right. \\
& \left.\hat{U}_{h^{t} \mid S_{t}, h_{t-1}, i_{t-1}, j t-1}, \forall h_{t}^{\prime} \neq h_{t}\right\} .
\end{aligned}
$$

ここに, $\quad h_{t}: t$ 時点の世帯構成の選択肢

$i_{t-1}: t-1$ 時点の居住地の選択肢

$j_{t-1}: t-1$ 時点の従業地の選択肢

$S_{t}: t$ 時点における個人属性

$\widehat{U}_{h t \mid}$ ：・なる条件のもとで評価した $t$ 時点の 世帯構成 $h_{t}$ の効用. ここで, ‘は将来効 用が含まれることを示す記号である。

式(2)における $\widehat{U}_{h t \mid}$. は, $t$ 時点において $h_{t}$ を含んだ 条件のもとで行われる居住地選択, 従業地選択, さらに $t+1$ 時点以降の各時点で行うと想定されている，世帯構 成選択，居住地選択，従業地選択から得られると期待さ れる最大効用を含んでいる.したがって,この $\widehat{U}_{h t \mid}$. は,

$$
\begin{aligned}
\widehat{U}_{h_{t \mid} \cdot}= & U_{0}+\max _{i_{t}}\left\{U_{1}+\max _{j_{t}}\left\{U_{2}+\max _{h_{t+1}}\left\{U_{3}+\right.\right.\right. \\
& \max _{i_{t+1}}\left\{U_{4}+\max _{j_{t+1}}\left\{U_{5}+\max _{h_{t+2}}\left\{U_{6}+\cdots \cdots+\right.\right.\right. \\
& \left.\left.\max _{j_{t+n}}\left\{U_{7}\right\}\right\} \cdots\right\} \cdots \cdots \cdots \cdots \cdots \cdots \cdots \cdots \cdots \cdots \cdots \cdots \cdots \cdots \cdots \cdots \cdots \cdots \cdots \cdots \cdots \cdots
\end{aligned}
$$

ここに, $U_{0}=U_{h t \mid s_{t}, h_{t-1}, i_{t-1}, j_{t-1}}, \quad U_{1}=U_{i t \mid s_{t}, h_{t, i t-1}, j_{t-1}}, \quad U_{2}=$

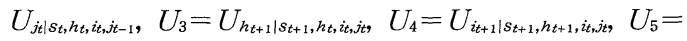
$U_{j t+1} \mid s_{t+1}, h_{t+1}, i_{t+1}, j_{t}, \quad U_{6}=U_{h_{t+2} \mid s_{t+2}, h_{t+1}, i_{t+1}, j_{t+1}}, \quad U_{7}=U_{j_{t+n} \mid s_{t+n}}$, $h_{t+n}, i_{t+n}, j_{t+n-1}$, 書くことができる.なお, 将来効用には, 式 (1)に示す割引乗数が含まれている.

ランダム効用理論に基づく非集計行動モデルにおいて は, 式 $(3)$ の各効用項は, 個人により変動するものとし て扱われる.この各効用項は，観測が可能で確定的に変 動する確定的変動項 $V$ と確率的に変動する確率的変動 項 $\varepsilon の$ 和で表わされるものと仮定される。すなわち, 式 ( 3 )の最終項を例にとるなら

$$
U_{j t+n \mid}=V_{j t+n \mid}+\varepsilon_{j t+n \mid} \cdot \cdots
$$

と表わすことができる。ここで, 式 (4)の右辺第 2 項が 最頻値 0 , 分散パラメーター $\lambda_{j n}\left(\lambda_{j_{n}}\right.$ は $\varepsilon_{j t+n}$. . の分散 $\sigma_{j_{n}}^{2}$ の $t$ 時点での評価値 $\left(C^{n} \cdot \sigma_{j n}\right)^{2}$ に対応するパラメーターで $\left(C^{n} \cdot \sigma_{j n}\right)^{2}=\pi^{2} / 6 \lambda_{j n}^{2}$ の関係がある. $)$ の Gumbel 分布に従 うと仮定するならば, 式 $(3)$ の最終項は

$$
\max _{j t+n}\left\{U_{j t+n \mid} \cdot\right\}=\Lambda_{j t+n \mid}^{*}+\varepsilon_{j t+n \mid}^{*} \cdot
$$

ここに,

$$
\Lambda_{j_{t+n} \mid \cdot}^{*}=\frac{1}{\lambda_{j n}} \ln \sum_{j^{\prime} t+n} \exp \left\{\lambda_{j n}\left(V_{j^{\prime \prime} t+n}\right)\right\}
$$

のよjになる.ここで, $\Lambda_{j t+n}^{*}$. はログサム変数であり, 上 位レベル $\left(t+n\right.$ 時点での居住地選択 $i_{t+n}$ のレベル, 上位 下位の関係は図一 1 参照）で $i_{t+n}$ を選択したときの, 
$U_{t_{t+n} \mid}$.の最大効用の最頻值を示している.なお, 式 $(5)$ に おける*印は，最適な選択がなされたことを示す記号で ある。このログサム変数は上位レベルの選択問題では

$$
\max _{i t+n}\left\{U_{i t+n \mid}+\Lambda_{j t+n \mid}^{*}+\varepsilon_{j t+n \mid}^{*}\right\}
$$

のような形で考慮されることになる，なお，式の操作の 便宜上，ここにおけるログサム変数の添字を上位レベル の効用の添字に統一しておく $\left(\Lambda_{i t+n \mid}^{*} \equiv \Lambda_{j t+n \mid}^{*} \cdot, \Lambda_{h_{t+n} \mid}^{*} \equiv \Lambda\right.$ ${ }_{\left.i_{t+n}\right]}^{*}$, 以降, ログサム変数の添字はこの表記規則に従う).

ここで, 式 $(7)$ の第 1 項を確定項と確率項に分けて表 示し確率項の和を

$$
\bar{\varepsilon}_{i t+n \mid} \equiv \varepsilon_{i t+n \mid}+\varepsilon_{j t+n \mid}^{*} .
$$

とおく.この $\bar{\varepsilon}_{i_{t+n} \mid}$. が再びパラメーター $\left(0, \lambda_{i n}\right)$ をもつ Gumbel 分布に従うと仮定し, 以上のプロセスを繰り返 せば式 ( 3 )は, 結果として

$$
\widehat{U}_{h t \mid}=U_{h t \mid}+\Lambda_{h t \mid}^{*}+\bar{\varepsilon}_{i t \mid}^{*} .
$$

ここに,

$$
\begin{aligned}
& \Lambda_{h_{t} \mid}^{*}=\frac{1}{\lambda_{i 0}} \ln \sum_{i t^{\prime}} \exp \left\{\lambda_{i_{0}}\left(V_{i^{\prime} t \mid \cdot}+\Lambda_{i^{\prime} t \mid}^{*}\right)\right\} \\
& \Lambda_{i t \mid \cdot}^{*}=\frac{1}{\lambda_{j 0}} \ln \sum_{j t^{\prime}} \exp \left\{\lambda_{j 0}\left(V_{j^{\prime} t \mid}+\Lambda_{j t \mid}^{*}\right)\right\}
\end{aligned}
$$

$$
\Lambda_{h_{t+n} \mid \cdot}^{*}=\frac{1}{\lambda_{i n}} \ln \sum_{i t+n} \exp \left\{\lambda_{i_{n}}\left(V_{i^{\prime} t+n \mid} \cdot+\Lambda_{i^{\prime} t+n \mid}^{*} \cdot\right)\right\}
$$

$$
\Lambda_{i t+n \mid \cdot}^{*}=\frac{1}{\lambda_{j n}} \ln \sum_{j^{\prime} t+n} \exp \left\{\lambda_{j_{n}}\left(V_{j^{\prime} t+n \mid} \cdot\right)\right\}
$$

となり,さらに，

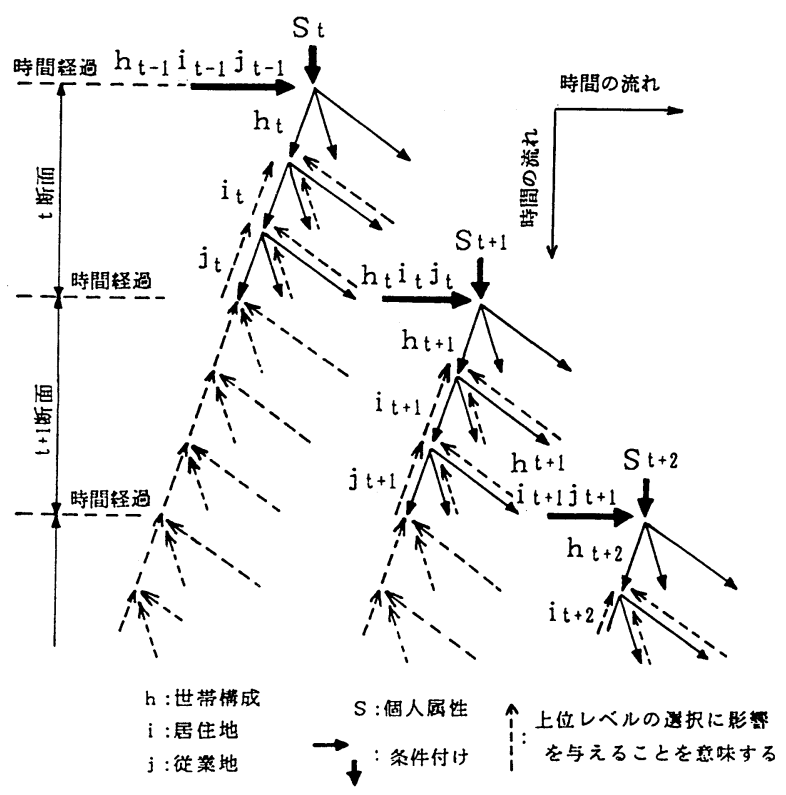

図一 1 意思決定のッリー構造
$\widehat{U}_{h t \mid}=V_{h_{t \mid}} \cdot+\varepsilon_{h t \mid}+\Lambda_{h t \mid}^{*}+\bar{\varepsilon}_{i t \mid}^{*} \cdot$

と書き改めることができる，この確率項の和が再びパラ メーター $\left(0, \lambda_{i_{0}}\right)$ をもつ Gumbel 分布に従うと仮定す ることにより, $t$ 時点における世帯構成 $h_{t}$ の選択確率は

$$
P_{h t \mid}=\frac{\exp \left\{\lambda_{h_{0}}\left(V_{h_{t} \mid}+\Lambda_{h t \mid}^{*}\right)\right\}}{\sum_{h t} \exp \left\{\lambda_{h_{0}}\left(V_{h^{\prime} \mid}+\Lambda_{h t \mid}^{*} \cdot\right)\right\}}
$$

となる。

一方, $t$ 時点における居住地 $i_{t}$ の選択確率 $P_{i_{t} \mid s_{t}, h_{t}, i_{t-1}, j_{t-1}}$ (以下, $P_{i t \mid}$. と略す), 従業地 $j_{t}$ の選択確率 $P_{j t \mid s t, h t, i t, j t-1}$ (以 下， $P_{j_{t \mid}}$. と略す)も，それぞれ世帯構成選択の場合と同様 のプロセスをたどることにより

$$
\begin{aligned}
& P_{i t \mid}=\frac{\exp \left\{\lambda_{i_{0}}\left(V_{i_{t} \mid}+\Lambda_{i t \mid}^{*}\right)\right\}}{\sum_{i t} \exp \left\{\lambda_{i_{0}}\left(V_{i^{\prime} t \mid}+\Lambda_{i^{\prime} t}^{*} \cdot\right)\right\}} \\
& P_{j t \mid}=\frac{\exp \left\{\lambda_{j 0}\left(V_{j t \mid}+\Lambda_{j t \mid}^{*}\right)\right\}}{\sum_{j t} \exp \left\{\lambda_{j 0}\left(V_{j^{\prime} t \mid}+\Lambda_{j^{\prime} \mid}^{*} \cdot\right)\right\}}
\end{aligned}
$$

となる。

$t$ 時点の世帯構成, 居住地, 従業地の同時選択確率は, (15)，（16）（17）の各式の積で与えられ，

$P_{h_{t}, i_{t}, j_{t} \mid S_{t}, h_{t-1}, i_{t-1}, j_{t-1}}=P_{h_{t} \mid} \cdot P_{i_{t} \mid} \cdot P_{j_{t} \mid} \cdot$

となる。なお, 転出量, 帰還量は, 式(18)から得られる 個人の選択確率に付随人数を乗じ，それを合計すること により算定される.

\section{5 ． 行動実績データに基づくモデル構造の検 討}

ここでは，調査によって得た過去の行動実績デー夕を 用いて本モデルのパラメーターを推定し，その適合度を 検討することを通じて，モデルに組み込んだ農 山村特有の行動規定要因の有効性や世帯構成・ 居住地・従業地の同時選択構造の妥当性を検証 するとともに，前期の選択状態の考慮や将来効 用の考慮といったモデルの動学的構造の妥当性 を検証する。すなわち，ここでの目的は，定住 施策評価において必要となる転出・帰還行動モ デルの基本的構造に対して行った本研究の考察 の妥当性を行動実績データから検証することで ある.したがって，ここでの検証は，具体的な 施策に対応した政策変数を十分に組み込んだ実 用レベルでの適用とはなっていないが，これに ついては, 今後の課題とする。

\section{（1）分析対象地域と分析対象者の概要}

分析対象地域である鳳来町は，東三河山間部 の最南部に位置し(図一 2 参照)，豊橋市などの 平野部都市域と接した典型的な都市近郊型の農 山村である。当地域は, 高度経済成長期以降, 過疎化の進行がみられ，新旧過疎法による過疎 指定を受けてきたが，都市域とのアクセシビリ 
ティーの改善，生活関連諸施設の整備等の定住施策の蓄 積が近年になり顕著な効果をみせ始め, 帰還者の増加等 により人口が横ばいに推移し始めている.昭和 60 年 3 月 末現在の本籍人口は 26669 人であり, そのうち鳳来町内 居住者は 16000 人, 町外居住者の約 $75 \%$ は隣接の都市域 を中心とした愛知県内に居住している.

\section{(2) 調査の概要}

本モデルの検証では, 分析対象者の個人データとして, 過去の数時点の居住地, 従業地, 世帯構成の同時選択行 動結果, ならびに各時点に対応した個人属性, ライフサ イクルステージが必要となる。このため, 表一 1 に示す 実施要領に従いアンケート調査を実施した，調査は，昭 和 63 年 9 月末現在での鳳来町内居住者 1500 人, 町外居 住者 527 人を対象に別々に実施し，回収率はそれぞれ $52.4 \%, 37.8 \%$ であった. 調査項目は, 昭和 40 年から昭 和 60 年の 5 年間隔 5 時点, 各 1 月 1 日現在での個人属 性, 居住地, 従業地, 世帯構成, ならびに, ライフサイ クルステージにかかわる要因（親, 兄弟の生存, 就業状 態，続柄，家産の継承状態など）である．なお，この2

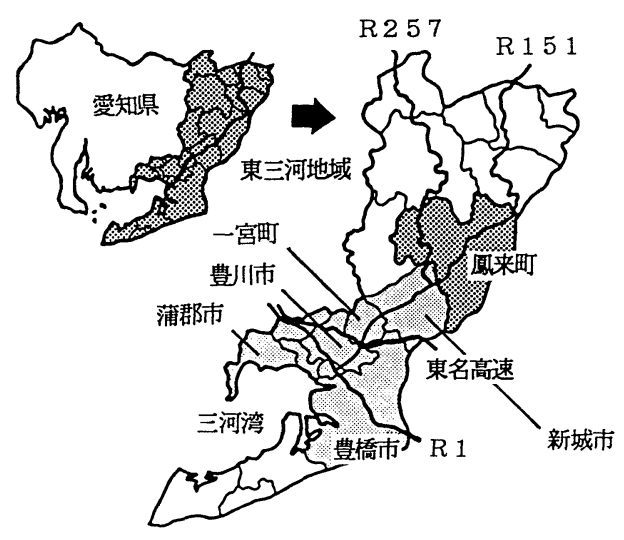

図一2 分析対象地域 (鳳来町) の位置

表一 1 アンケート調査の概要

\begin{tabular}{|c|c|c|}
\hline & A: 鳳来町内居住者調査 & B:凰来町外居住者調査 \\
\hline $\begin{array}{l}\text { アンケート } \\
\text { 対象者 }\end{array}$ & $\begin{array}{l}\text { 風来町選挙人名簿 } \\
\text { より男性について } \\
\text { 無作為抽出* }\end{array}$ & $\begin{array}{l}\text { A調査より得た町 } \\
\text { 外居住の分析珓象 } \\
\text { 者全買 }\end{array}$ \\
\hline 調査年月日 & 1988年10月 5日 & 1988年12月 20 日 \\
\hline 配布数 & 1,500 & 527 \\
\hline $\begin{array}{c}\text { 配布·回収 } \\
\text { の方法 }\end{array}$ & $\begin{array}{l}\text { 訪問配布 } \\
\text { 郵送回収 }\end{array}$ & $\begin{array}{l}\text { 郵送配布 } \\
\text { 郵送回収 }\end{array}$ \\
\hline 回収数 & 796 & 199 \\
\hline 回収率 & $52.4 \%$ & $37.8 \%$ \\
\hline
\end{tabular}

* 本調查では便宜上主たる家計支持者を男性のみとした。
つの調査により得られたデー夕は, 調査時点で町内居住 者か, 町外居住者かといった, 居住地選択結果によるチョ イスベーストサンプリングであるため, 抽出率の相違に よる補正を施している.

\section{（3）検証方法}

本モデルでは, 世帯構成, 居住地, 従業地の多次元選 択の同時選択問題を, 離散的な時間の流れの中で動学的 に扱っている。これに従って忠実にモデルの検証を行う ならば, たとえば $t$ 時点の居住地選択行動は, それにか かわる $t$ 時点の他の行動（世帯構成選択，従業地選択） と, それまで（ $t-1$ 時点以前）の行動履歴に条件付けら れ，かつ， $t$ 時点以前の行動履歴に条件付けられた $t+1$ 時点以降の選択肢群から得られると考えられる将来効用 を考慮した行動として扱われなければならない.また， このときの選択行動の主体としては, 将来にわたる自ら にかかわる属性の変化と社会経済環境を完全予知した理 想的個人が想定されている。しかし，個人の予知する将 来は不確定な要素を多分に含んでおり, 実際の行動にお いては, ある程度の将来を考慮しつつも近視眼的な行動 形態をとっているものと考えられる．このためここでの 検証においては，時点の間隔を 5 年に設定したうえで, 行動履歴による条件付けについては, $t-1$ 時点の行動実 績のみを $t$ 時点の選択行動の説明変数として組み込み, 将来効用の考慮については, $t$ 時点の選択肢に条件付け られた $t+1$ 時点のみの選択肢群から得られると考えら れる将来効用の期待值をログサム変数を介して考慮する こととする。このことは, 個人が将来を考慮する範囲が せいぜい 5 年程度であると仮定することに等しい. した がって, 本研究の適用から, 現実の選択行動においてど の程度先までの将来を考慮しているのかは検討できな い.この問題については，今後の検討課題とする，また， 本研究の適用では, 行動主体は, $t$ 時点の選択行動におい て考慮した $t+1$ 時点の将来効用の認知において, $t+1$. 時点において実現した個人属性および社会経済環境をほ ぼ的確に予見していたものと仮定する.

以上の方針に従い本モデルのパラメーター推定を行っ た. 推定時点は昭和 55 年であり, 推定方法は, 図一 1 で 仮定した意思決定のツリ一構造の下位段階から上位段階 へ順に推定作業を行う段階推定法である。

\section{(4) 推定結果とその考察}

本モデルのパラメーター推定において設定した選択肢 は，居住地，従業地については，(1)鳳来町，(2)隣接都市 域 ( 4 市 4 町), (3)その他地域であり, 隣接都市域とその 他地域については，鳳来町からの通勤可能圈か否かによ り区分した。 また，世帯構成については，(1)親同居，(2) 親非同居・非単身，(3)親非同居・単身である.

本モデルの各レベルにおける効用関数としては加法線 
形型の効用関数を用いている. これらの効用関数の説明 変数の多くは, 選択肢と個人属性, 選択肢と関連する他 の行動の組合せによるダミ一変数である(表一 2 参照). これらのダミ一変数のうち, 居住地と従業地に関するダ ミ一変数は, 地域の居住環境や就業環境を構成する種々 の社会経済指標を包括的に表現した指標が個人属性や関 連する他の行動結果との組合せで評価されるものとして 用いる.このため, 実際に将来予測や施策評価を行う際 にはより具体的な社会経済指標を政策変数として導入し たモデルの作成が必要となるが，これについては今後の 課題とする.なお, 各効用関数の説明変数組については, 変数相互の関係を考慮しつつ妥当な推定結果が得られる 組合せを採用することとしている.

従業地, 居住地, 世帯構成の各レベルにおけるパラメー 夕一推定の結果をそれぞれ表一 $3,4,5$ に示す.ここで は前期条件, 将来効用とも考慮しないモデルに対して, それぞれ前期条件，将来効用を考慮することでモデルの 適合度がどの程度向上するのかを検討する．まず全体を

\section{表一2 選択肢, 説明変数の一覧}

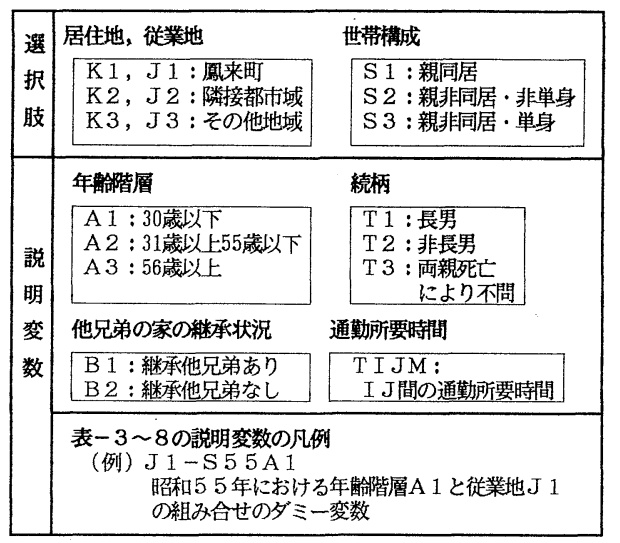

表一 3 昭和 55 年従業地選択の推定結果

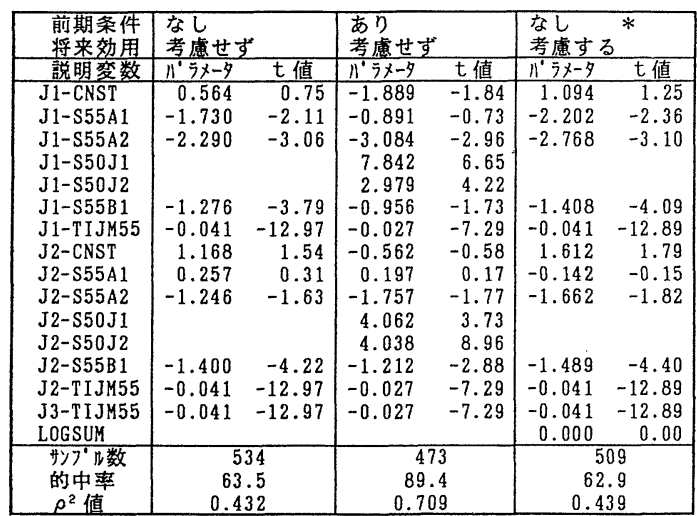

*ここでの定式化では，前期条件がない時すべての選択肢に同じ

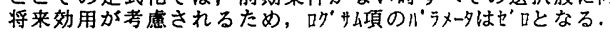

通じて，各レベルとも効用最大化仮説の整合条件 ${ }^{18)}$ を満 たし, $t$ 值もほぼ妥当な推定結果が得られた.この中で注 目すべきことは, 農山村出身者の行動において特に重要 と考え導入した，他兄弟の継承者の存在（表一 3 参照）， 続柄（表一 5 参照）の推定結果である。まず，他兄弟の 継承者が存在する者（B 1) は，従業地の選択において， $\lceil\mathrm{J} 1$ ：鳳来町」,「J 2 ：隣接都市域」との組合せのパラメー ターがいずれも負であり，相対的に「J 3 ：その他地域」 を高く評価している.これは，家の継承義務から開放さ れることで，鳳来町に縛られることなく大都市圏等の就 業環境が良い地域に従業地を選択しやすくなることを示 すものである.一方, 続柄においても, 長男 (T 1)の「S 1： 親同居」の評価は，「S $2 \cdot \mathrm{S} 3$ : 親非同居」に対して相対 的に高く，長男の親との同居が慣例として行われている 現状をよく反映した結果となっている，このことは，居 住地選択（表一 4 参照）においても，鳳来町と世帯構成 選択の親同居カテゴリーの組合せダミ一変数（K 1-S 55 S 1) のパラメーターの高さに反映されている．以上のよ うに，本研究において特に重要として考慮した他兄弟の 継承状況，続柄などの属性が有意に作用することを示す ことが確認できた.

次に，表一 3 に示す従業地選択では居住地の条件付き で与えられる通勤時間（J 1，J 2，J 3-TIJM 55）が，ま た表ー 4 に示す居住地選択では世帯構成のダミー変数

\section{表一 4 昭和 55 年居住地選択の推定結果}

\begin{tabular}{|c|c|c|c|c|c|c|}
\hline $\begin{array}{l}\text { 前期条件 } \\
\text { 将来効用 }\end{array}$ & \multicolumn{2}{|c|}{$\begin{array}{l}\text { なし } \\
\text { 考慮せず }\end{array}$} & \multicolumn{2}{|c|}{$\begin{array}{l}\text { あり } \\
\text { 考虑せず }\end{array}$} & \multicolumn{2}{|c|}{$\begin{array}{l}\text { なし } \\
\text { 考慮する }\end{array}$} \\
\hline 説明変数 & $11^{1} 5 x-4$ & $\mathrm{t}$ 值 & $11^{\circ}$ ラx-4 & t值 & $115 x-3$ & 七値 \\
\hline K1-CNST & -1.089 & -0.95 & -5.285 & -3.14 & -1.636 & -1.42 \\
\hline K $1-S 55 A 1$ & -2.584 & -4.32 & -2.708 & -2.35 & -2.023 & -3.28 \\
\hline $\mathrm{K} 1-\mathrm{S} 55 \mathrm{~A} 2$ & -0.022 & -0.05 & -0.408 & -0.43 & 0.461 & 0.88 \\
\hline $\mathrm{K} 1-\mathrm{S} 50 \mathrm{~K} 1$ & & & 5.857 & 6.71 & & \\
\hline K1-S50K2 & & & 3.136 & 3.34 & & \\
\hline K1-S55S1 & 7.543 & 6.65 & 9.695 & 6.46 & 7.538 & 6.64 \\
\hline $\mathrm{K} 1-\mathrm{S} 55 \mathrm{~S} 2$ & 1.760 & 1.63 & 2.343 & 1.85 & 1.752 & 1.62 \\
\hline K2-CNST & -0.700 & -1.54 & -1.764 & -2.13 & -1.171 & -2.35 \\
\hline K2-S55A1 & -0.479 & -1.03 & 0.573 & 0.61 & 0.062 & 0.13 \\
\hline K2-S55A2 & 0.936 & 1.85 & 1.064 & 1.21 & 1.415 & 2.56 \\
\hline K2-S50K2 & & & 3.430 & 6.70 & & \\
\hline LOGSUM & 0.849 & 4.87 & 0.799 & 5.28 & 0.793 & 4.83 \\
\hline サソプル数 & & & & & & \\
\hline 的中專 & & & & & & \\
\hline$\rho^{2}$ 值 & 0.4 & & & & & \\
\hline
\end{tabular}

表一 5 昭和 55 年世帯構成選択の推定結果

\begin{tabular}{|c|c|c|c|c|c|c|}
\hline $\begin{array}{l}\text { 前期条件 } \\
\text { 将来効用 }\end{array}$ & \multicolumn{2}{|c|}{$\begin{array}{l}\text { なし } \\
\text { 考虐せず }\end{array}$} & \multicolumn{2}{|c|}{$\begin{array}{l}\text { あり } \\
\text { 考慮せず }\end{array}$} & \multicolumn{2}{|c|}{$\begin{array}{l}\text { なし } \\
\text { 考慮する }\end{array}$} \\
\hline 説明変数 & $11=5 x-4$ & 七值 & $1^{1}$ ラx-4 & $\mathrm{t}$ 值 & $n^{\prime} 5 x-y$ & 七值 \\
\hline S1-CNST & 0.233 & 0.13 & 1.577 & 1.59 & -0.736 & -0.37 \\
\hline S1-S55A1 & -2.606 & -3.16 & -2.301 & -3.29 & -2.284 & -2.68 \\
\hline $\mathrm{S} 1-\mathrm{S} 55 \mathrm{~T} 1$ & 0.711 & 1.88 & 0.351 & 0.59 & 0.671 & 1.77 \\
\hline S2-CNST & 5.290 & 8.31 & 5.247 & 6.02 & 5.207 & 8.15 \\
\hline$S 2-S 55 A 1$ & -4.486 & -7.18 & -3.244 & -4.42 & -4.422 & -7.07 \\
\hline S2-S50S1 & & & -1.891 & -3.84 & & \\
\hline S2-S50S2 & -1.714 & -4.54 & $\begin{array}{r}2.105 \\
-2.038\end{array}$ & $\begin{array}{r}4.50 \\
-3.40\end{array}$ & -1.696 & -4.49 \\
\hline LOGSUM & 0.689 & $\begin{array}{r}-4.24 \\
2.02\end{array}$ & $\begin{array}{r}-2.038 \\
0.289\end{array}$ & $\begin{array}{r}-3.40 \\
3.61\end{array}$ & 0.886 & $\begin{array}{r}4.45 \\
2.33\end{array}$ \\
\hline サソブル数 & \multicolumn{2}{|c|}{534} & \multicolumn{2}{|c|}{473} & \multicolumn{2}{|c|}{509} \\
\hline 的中率 & \multirow{2}{*}{\multicolumn{2}{|c|}{$\begin{array}{r}76.4 \\
0.414\end{array}$}} & \multirow{2}{*}{\multicolumn{2}{|c|}{$\begin{array}{r}86.9 \\
0.699\end{array}$}} & \multirow{2}{*}{\multicolumn{2}{|c|}{$\begin{array}{r}75.8 \\
0.407\end{array}$}} \\
\hline$\rho^{2}$ 値 & & & & & & \\
\hline
\end{tabular}


（S 1-S 55 S 1）がそれぞれ有意であることが示されてお ク，本モデルで仮定した同時選択構造がほぼ妥当である ことを確認できた.

さらに，前期条件や将来効用の考慮については，前期 条件を考慮することにより各レベルにおいて適合度が大 きく向上することが読み取れる。一方，将来効用の考慮 については，考慮しない場合とほぼ同程度の適合度しか 得ることができなかった。 そこで，前期条件を考慮した モデルに，さらに将来効用を同時に考慮したモデルの推 定を行った。その結果が表一6，7，8である。これによ れば，ログサム変数のパラメーターが 1 を越すものがあ るため, 効用最大化の整合条件 ${ }^{18}$ は満たされないものの, パラメーターの統計的有意性についてはほぼ妥当な結果 を得ることができた.しかもいずれのレベルにおいても， 的中率， $\rho^{2}$ 值の少なくとも一方にわずかながらではある が向上が認められる，さらに，本研究で用いたデータが 時点間で相関が高かったこと，ここではモデルの基本構 造を検討するため説明変数を詳細に設定しなかったこと などにより，将来効用を考慮することの効果が必ずしも 十分に現われていないことが考えられる。これらのこと より，将来効用を考慮することの有効性は必ずしも否定 できず，前期条件の有効性を考之合わせるならば，本研 究で仮定した動学的モデル構造は, ほぼ妥当であるとい える。

\section{6.おわりに}

本研究では，農山村における転出・帰還行動をとりあ げ，まず，その行動メカニズムの考察と，それに基づく 定住施策評価のあり方を検討した。ここでは，過疎対策 の効果についての考察を行い, 過踈問題の根本的解決に は，効果的な定住施策がより重要であることを述べた。 次に，効果的な定住施策を実施するうえで必要となる転 出・帰還行動モデルについて, その構造がいかにあるべ

\section{表一 6 昭和 55 年従業地選択の推定結果}

（前期条件あり，将来効用考慮）

\begin{tabular}{|c|c|c|}
\hline 説明変数 & 11ラメータ & t 值 \\
\hline J1-CNST & -4.565 & -2.17 \\
\hline$J 1-S 55 A 1$ & -0.881 & 0.58 \\
\hline $\mathrm{J} 1-\mathrm{S} 55 \mathrm{~A} 2$ & -3.068 & -2.16 \\
\hline $\mathrm{J} 1-\mathrm{S} 50 \mathrm{~J} 1$ & 7.795 & 6.43 \\
\hline $\mathrm{J} 1-\mathrm{S} 50 \mathrm{~J} 2$ & 2.883 & 3.79 \\
\hline J1-S55B1 & -0.512 & -0.80 \\
\hline J1-T IJM55 & -0.019 & -3.58 \\
\hline J2-CNST & -1.317 & -0.91 \\
\hline $\mathrm{J} 2-\mathrm{S} 55 \mathrm{~A} 1$ & -0.767 & -0.52 \\
\hline J2-S55A2 & -2.401 & -1.76 \\
\hline $\mathrm{J} 2-\mathrm{S} 50 \mathrm{~J} 1$ & 4.021 & 3.69 \\
\hline $\mathrm{J} 2-\mathrm{S} 50 \mathrm{~J} 2$ & 3.978 & 8.87 \\
\hline $\mathrm{J} 2-\mathrm{S} 55 \mathrm{~B} 1$ & -0.927 & -2.07 \\
\hline J2-T IJM55 & -0.019 & -3.58 \\
\hline J3-T IJM55 & -0.019 & -3.58 \\
\hline LOGSUM & 1.564 & 1.96 \\
\hline +サソプ数 & \multicolumn{2}{|c|}{448} \\
\hline 的中率 & \multicolumn{2}{|c|}{89.7} \\
\hline$\rho^{2}$ 値 & \multicolumn{2}{|c|}{0.714} \\
\hline
\end{tabular}

\section{昭和 55 年居住地選択の推定結果}

(前期条件あり, 将来効用考慮)

\begin{tabular}{|c|c|c|}
\hline 説明变数 & $11^{0} 5 x-y$ & $\mathrm{t}$ 値 \\
\hline $\mathrm{K} 1-\mathrm{CNST}$ & -5.222 & -2.88 \\
\hline $\mathrm{K} 1-\mathrm{S} 55 \mathrm{~A} 1$ & -2.355 & -1.68 \\
\hline $\mathrm{K} 1-\mathrm{S} 55 \mathrm{~A} 2$ & 0.162 & 0.13 \\
\hline $\mathrm{K} 1-\mathrm{S} 50 \mathrm{~K} 1$ & 5.615 & 6.43 \\
\hline $\mathrm{K} 1-\mathrm{S} 50 \mathrm{~K} 2$ & 2.670 & 2.82 \\
\hline $\mathrm{K} 1-\mathrm{S} 55 \mathrm{~S} 1$ & 9.289 & 6.21 \\
\hline K1-S55S2 & 2.204 & 1.75 \\
\hline K2-CNST & -1.838 & -1.69 \\
\hline $\mathrm{K} 2-\mathrm{S} 55 \mathrm{~A} 1$ & 0.760 & 0.62 \\
\hline $\mathrm{K} 2-\mathrm{S} 55 \mathrm{~A} 2$ & 1.712 & 1.49 \\
\hline $\mathrm{K} 2-\mathrm{S} 50 \mathrm{~K} 2$ & 2.637 & 4.71 \\
\hline LOGSUM & 1.493 & 6.44 \\
\hline $\begin{array}{l}\text { 形プ数 } \\
\text { 的中率 }\end{array}$ & \multicolumn{2}{|c|}{448} \\
\hline$\rho^{2}$ 値 & \multicolumn{2}{|c|}{95.1} \\
\hline
\end{tabular}

\section{表一8 昭和 55 年世帯構成選択の推定結果} (前期条件あり, 将来効用考慮)

\begin{tabular}{|c|c|c|}
\hline 説明変数 & $11^{2} 5 x-y$ & 七值 \\
\hline S1-CNST & 2.301 & 2.01 \\
\hline S1-S55A1 & -2.292 & -2.97 \\
\hline S1-S55T1 & 0.260 & 0.44 \\
\hline S2-CNST & 6.170 & 7.21 \\
\hline S2-S55A1 & -3.709 & -5.13 \\
\hline $\mathrm{S} 2-\mathrm{S} 50 \mathrm{~S} 1$ & -2.581 & -5.88 \\
\hline S2-S50S2 & 1.997 & 4.28 \\
\hline S2-S55T 1 & -1.972 & -3.19 \\
\hline LOGSUM & 0.436 & 1.99 \\
\hline $\begin{array}{l}\text { Hソプ 擞 } \\
\text { 的中率 } \\
\rho^{2} \text { 値 }\end{array}$ & \multicolumn{2}{|c|}{$\begin{array}{r}448 \\
87.5 \\
0.691\end{array}$} \\
\hline
\end{tabular}


方々に謝意を表する次第である，なお，本論文は著者の 1 人片田が, 豊橋技術科学大学に提出した学位論文 (主 查：三宅醇教授）の一部である.

\section{参 考 文 献}

1）国土庁地方振興局過疎対策室監修：過疎対策の現況, 1989.

2）大西 隆：若青年層の人口移動に関する実証的研究，第 17 回日本都市計画学会学術研究論文集, pp. $31 \sim 36$, 1981.

3）中島尚志・大西 隆：地方都市における若青年層の定住 と流出に関する研究，都市計画論文集，No. 23, pp. 247 252, 1988.

4）折田仁典・清水浩志郎：DEMATEL 法による過疎問題 の構造化に関する基礎的研究，都市計画論文集，No. 23， pp.289 294, 1988.

5）森川 稔：農山村転出後継者の帰還意向に関する分析, 日本建築学会論文報告集, 第 339 号, pp.112 121, 1984.

6）青島縮次郎・伊縫憲幸・片田敏孝：山村定住のための環 境整備, 環境情報科学, Vol. 13, No. 3, pp.59 67, 1984.

7）青島縮次郎・片田敏孝・越野実雄・加藤慎一：農山村に おける都市近郊型定住の進展とその特質に関する実証的 研究一愛知県三河山間地域を事例として一, 第 22 回日本 都市計画学会学術研究論文集, pp.319 324, 1987.

8）清水浩志郎・折田仁典：過疎化過程の把握と人口移動モ チベーションに関する考察, 環境情報科学, Vol. 10, No. 4, pp.51〜 59, 1981.

9）森川 稔：農山村における帰還者および新来者に関する 分析，日本建築学会論文報告集，第 353 号，pp.92 102, 1984.

10）片田敏孝・廣畠康裕・青島縮次郎：農山村住民の転出・ 帰還行動における意思決定の構造に関する研究, 都市計 画論文集, No. 24, pp.37〜42, 1989.

11）岡田憲夫・亀田雄二：過疎地域の経済活性度に関する研
究一生活支援施設の経営成立性からみて一, 土木計画学 研究・論文集, No. 4, pp.29 36, 1986.

12）萩原清子：過疎問題の経済学的考察, 地域学研究, 第 15 卷, pp.185 211, 1985 .

13）石橋正穂：地方定住のための地方道路網の整備, 道路, No. 11, pp.34 37, 1985.

14）石島治四郎：農村工業導入と地域形成, 環境情報科学, Vol. 10, No. 2, pp.19 26, 1981.

15）青島縮次郎・片田敏孝：農山村定住の動向分析, 環境情 報科学, Vol. 15, No. 4, pp.55 61, 1986.

16）定井嘉明・森谷久吉・近藤博士：住民のニーズに基づく 過疎対策に関する研究, 土木学会論文報告集, 第 277 号, pp.105 112, 1978.

17）片田敏孝・青島縮次郎・氷鉋揚四郎：農山村・都市間関 係におけるライフステージを考慮した居住地・従業地選 択行動モデル, 地域学研究, 第 18 巻, pp.1〜18, 1989.

18) Williams, H.C.W.L. : On the Formation of Travel Demand Models and Economic Evaluation Measures of User Benefit, Environment and Planning A, Vol. 9, pp.285 344, 1977.

19) Leonardi, G.: A Stochastic Multi-stage Mobility Choice Model, The International Symposium on New Directions in Urban Modelling, 1983.

20）片田敏孝・廣畠康裕・青島縮次郎：農山村における定住 政策評価のための広域居住地選択モデル，土木計画学研 究・講演集, No. 11, pp.179 186, 1988.

21）廣畠康裕：交通施設に対する地域住民の評価と交通行動 の分析方法に関する研究, 学位論文, pp.9 14, 1986.

22）杉恵頼寧・藤原章正：選好意識デー夕を用いた交通手段 選択モデルの有効性, 交通工学, Vol. 24, No. 5, pp. 21 30, 1989.

(1989.12.11・受付) 